\begin{tabular}{|c|c|}
\hline Uniqbu Journal of Social Sciences (UJSS) \\
E-ISSN: 2723-3669
\end{tabular}

\title{
DEPTH ANALYSIS CLASS AVERAGE OF 2013 NURSING STUDENTS AT MOLUCCAS CHRISTIANNUNIVERSITY OF INDONESIA
}

\author{
(Analisa Mendalam Rata Rata Kelas Mahasiswa Keperawatan Angkatan 2013 Universitas \\ Kristen Indonesia Maluku)
}

\author{
Debora Harsono \\ Fakultas Kesehatan, Universitas Kristen Indonesia Maluku \\ deboraharsono15@gmail.com
}

(Received 17 Januari; Revised 26 Januari; Accepted 30 Januari 2022)

\begin{abstract}
This research performs a reality about the Depth Analysis Class Average of 2013 Nursing Students at Moluccas Christian University of Indonesia. The method that written uses is descriptive study. To achieve the credibility of data for this research, the writer would like use the data of Class Average five classes $(A-E)$ Nursing students of 2013 generations, namely graphic and table. Finally, the research findings that $E$ class has the lowest class average than the others classes. It happens because more than half of $E$ class students achieve the grade below C point. In short, we can conclude the real data of E class that performs by 2013-specifically E class, Nurses students of UKIM.
\end{abstract}

Keywords: Depth Analysis, Class Average, 2013 generations

Abstrak

Makalah ini menghadirkan sebuah realita tentang Analisa Mendalam dari mahasiswa Keperawatan Angkatan 2013 pada Univeristas Kristen Indonesia Maluku. Metode yang digunakan adalah penelitian deskriptif. Untuk mencapai kredibilitas data, peneliti menggunakan Data Tabel Nilai dan Grafik Rata Rata Kelas dari lima kelas (A--E) mahasiswa keperawatan Angkatan 2013. Hasilnya menunjukkan bahwa kelas E mendapatkan rata rata kelas terendah, daripada pada kelas lainnya. Karena separuh mahasiswa dalam kelas $E$ mendapatkan nilai dibawah C. Ringkasnya, kami dapat menyimpulkan bahwa terdapat data data kongkrit yang ditunjukkan oleh mahasiswa Keperawatan Angkatan 2013-- khususnya kelas E, UKIM

Kata Kunci: Analisa Mendalam, Rata Rata Kelas, Angkatan 2013

\section{INTRODUCTION}

After teaching about 11 years in UKIM (Moluccas Christian University of Indonesia), the researcher had taught almost 10 generations. Every generations has their own characteristics. Years by years, every generations come every generations gone.
Every generation leave their personal impression for the writer. Personally, the 2013 generation gives special impression for the writer. And this thing encourage me personally to conduct in depth analysis about them. Now, the writer would like to describe vividly by Seeing Depth Analysis the Class Average 
2013 generations of Nursing Students-Moluccas Christian University of Indonesia. Class

Average is usually obtained after the teaching and learning process really ends. That means it is very unlikely that average grade obtained at the beginning of the semester or Mid Term. At the end of the semester, ideally the subject from all the teachers and lecturers should calculate and analyze the results of the teaching learning process to get grade. Because by getting the score of the achievement goals on the teaching and learning process, it will be more measurable and real. With a series of these numbers, the teachers and lectures can compare the results of learning this class with the result of other classes (this subject with other subjects). Finally, the results of the class average will be a real benchmark to achieve the level of success of the teaching learning process that has been carried out in one semester.

Score / grade average is not only the realization of a series of numbers. But it can also be the result of feedback for the teachers, as the reflection of all material that has been taught. This teaching learning process will be ending at the semester evaluation. Score / grade average is not only the proof / result of teaching learning process, but it can also as the representative ability of the students on the whole of running semester.

Without any score / grade, how can the teachers / lecturers can do the measurement systems of teaching learning evaluation at the end of the semester ? So, the score / grade plays the most important role on the teaching learning process of the whole running semester. Score / grade could not be separated from teaching learning process. It must be unity, inseparable, inter related, whole as one.

Later, all the evaluation processes referred to the acquisition of round numbers to be determined as a standardization of student graduation levels in the form of achieving point of A / B / C or not passing D and E point. When we deliver them the point of $\mathrm{A} /$ $\mathrm{B} / \mathrm{C}$ on student sheets, or inputting points at online system, they often assume these tasks and obligations have been completed. Though there is still one final task that must be done with all seriousness. The task needs to calculate and analyze the Class Average. So, the Class Average is final step or task of teachers or lecturers need to do on the end of semester.

The Class Average is directly related with teaching and learning process and has been running for one semester. The Class Average is not the average point of a student, but the overall points that obtained of one class and is divided by the number of students in one class / in one course for one subject on that semester. The Class Average is directly related with many aspects of the existence of students and teachers or lecturers. These aspects are : First, the continuity / presence of students for directly involve on the teaching and learning process from early up to the end of semester.

Second, the steadiness of teaching materials that have been prepared by the lecturers. Third, the perseverance of students to study and prepare daily assignment material, group presentations, study well for Mid Terms and Final Test. $\quad \underline{\text { Forth}}$, the commitment of teachers for delivering all teaching material. All these aspects are interrelated and inseparable. The Class 
Average can be influenced by some various factors. The factors are such as an interest on learning, the achievement of individual assign- ments, group presentation, the results of Mid Terms and Final Test scores. All of these factors are interrelated and inseparable. Each factor need to be supported for the others. From all the factors preciously says, the writer will discuss next about the interest.

Interest is one of the main aspects from teaching learning process. Interest is first step for someone to do something because of likeness. Without any interest someone or something could not be well done. On teaching learning process interest aspect plays the important role to accomplish the assignment, doing well the mid and final test. Because of interest the students like and eager to attend the class of the whole running semester.

Furthermore, the writer would like to describe vividly about the data of 2013 generation of nursing students.

In this research, 2013 generations consist of five classes $(\mathrm{A}-\mathrm{E})$. But the Class Average of $E$ class proves the lowest point. And the amount of the students number do not a minimum one. D Class has the minimum students (35 students).

Herewith the Point Class Average of A-E classes 2013:

A class $=60.64$ point

$\mathrm{B}=65.21$ point $\mathrm{C}=66.22$ point

$\mathrm{D}=64.17$ point $\mathbf{E}=\mathbf{5 6 . 8 0}$ point

Herewith the Obtaining data point of English II for the seventh semester of 2013 generations of E class. The total numbers are 42 students.
$A+=0$ students
$B+=3$ students
$A=0$ student
$B=7$ students
$A-=2$ students
$B-=6$ students

$\mathrm{C}+=4$ students

$\mathrm{D}=8$ students

$\mathrm{C}=6$ students

$\mathrm{E}=0$

C- $=2$ students

From the data provides about the Obtaining Process of English II point for the seventh semester of one generation in details. From this data, there is arising one question, why there is one class (E class) states the lowest Class Average?

Meaning, there are four classes (AD) have Class Average around 60 or more than 60 point. According to the data performs there is no one of the students that can achieve A+ and A point. Contradictory, there are many students get $\mathrm{C}+$ point (4 students), C point (6 students), and C-point (2 students), finally D point (8 students). All of these students achieved the standard point $\mathrm{C}+$ down to D. These numbers totally are 20 students. It means almost a half of $\mathrm{E}$ class get the standard point. Because the amount students numbers of E class are 42 students.

In fact, these data would be the interesting aspects for the researcher to conduct the research not about the Comparison anymore (it had before) but the researcher will be discussed it, in Depth Analysis Class Average Research.

\section{THEORETICAL REVIEW}

In Depth Analysis theory consists of two words. They are : Depth and Analysis. The researcher would like to describe vividly about that two words.

I. First Analysis : the meaning of analysis are :

1. To divide into separate parts.

2. Examine carefully in order to find out about.

3. To divide into its various part. Analysis is not a summary. An analysis may summarize these ideas but it also : 
1. Identifies main

ideas.

2. Describes what

points make up the ideas.

3. Examines relationships between ideas and points.

4. Evaluates the quality of the evidence used to support the ideas.

Some points about Analysis: The meanings of Analysis are :

1.

Analysis means asking question.

Explore what ideas appear inside a text.

3.

Think about Why you are doing.

To think deeper and wider.

There are four steps of Analysis Process :

Step 1 : What

? Reword of quote ? Step 2 : What ? What idea is inside of these quoted words?

Step 3 : How ? Explain to the reader how to understand content of this research. Step 4 : Why ? Why is the idea found in the quote important to the meaning of the research?

II. Second Depth : Depth is a noun (kata benda). Meaning as a noun depth :

1. The vertical distance below a surface.

2. The degree to which something is deep.

3. The distance between the front and the back intensity, complexity, strength seriousness / importance of an emotion, situation, etc.

On this research, the researcher would like to conduct in Depth Analysis. Because there is only one class that get the lowest point of Class Average of 2013. In fact, the others classes / four classes get the class average more than 60 point. This E class students do not with the minimum students number (42 students).

\section{RESEARCH METHOD}

In this research, the researcher uses a case study. The case study is descriptive, exploratory or exploratory analysis of a person, group or event, decisions, periods, projects, policies institutions or other systems which are studied holistically by one or more methods. The subject of this research are the students nursing program 2013 generations of UKIM, especially E class. They state the lowest Class Average than the other classes of 2013 generations.

4. This research is done at nursing study program of 2013 generations of UKIM ( The Moluccas Christian University of Indonesia).

The researcher tries to conduct the depth analysis on their Class Average. The researcher is interested of their performances about lowest Class Average. Why their Class Average shows the lowest one than the other class of 2013 generations? The validation of data and analysis result of this study is done by Triangulation Technique. The data Triangulation which involves observation, field note, interview, combines many data collecting techniques and sources. In this technique, the researcher uses various collecting data technique to obtain data from the same resources. Susan

Stainback stated that : "the aim is not to determine the truth about social phenomenon, rather the purpose of triangulation is to increase one's understanding of whatever is being investigated. Furthermore she stresses that what the qualitative researcher is interested in is not the truth per se, but rather the perspectives.

Thus, rather than trying to determine the "truth" of people's perceptions, the purpose of corroboration is to help researchers increase their understanding and 
probability that this finding will be seen as credible or worthy of consideration by others". Through Triangulation "we can build on the strengths of each type of data collection while minimizing the weakness in any single approach" (Supriyono 2012 : 241).

In this research the researcher uses Miles and Huberman;s model of the data analysis (1994) which consist of qualitative data analysis, data collection, data reduction, and conclusion. Data collection means that the researcher collects the data from observation, filed notes, in depth interview. All data are collected during the research. Data reduction means the selection of significant data and the trash of rubbish data.

\section{DISCUSSION}

Later, the researcher would like to discuss deeper and wider about the Class Average of 2013 generations of nursing study program students, especially E class.

Actually, we have these data of the Class Average on the end of the semester. It must be combined from the result of Personal Assignment, Group Discussion / Presentation, Mid Term Test and Final Test. We add all the result, later it is divided with the totaling student numbers of the class. So, we say this process by the Class Average. Absolutely, many aspects can influence the Class Average.

These aspects are, namely : psychological, physically, economic- ally, social aspects and others. Psychological aspects include the emotional, intellectual, and characters. Physically sides consist of biological, and medical. Economical describes as the financial aspects. Social status or background of the student family must affect the result of learning studying process.

Psychologically background is quite relevant with the performance of one students on his / her teaching learning process. It means, when their parents are hardly to motivate them to study seriously, so they must study without any laziness. Physically and economically are one package. This condition means, if their parents are really supported them economically. So they can buy more books, good nutrition for providing their needs to have good health and mind to be more focus on their studying. Because they do not need to find any job for getting some money to pay their fee. When they have more money to buy good nutrition and supplement, so they always have stable physically condition. All of these aspects are really can influence of the success of our students. The success of them in their studying can be measured by the lectures with analyzing the Class Average.

Class Average is the most important of teaching learning feedback. From the data of Class Average, we can measure of teaching learning process happens success or the fail one. Class Average plays the important roles on teaching leaning process on the semester. It is could not be separated from teaching leaning feedback. The Lecturers must accomplish their Class Average of every subjects from one's faculty on the end of semester. We could not neglect it, because without any Class Average results, how we can measured the success of our teaching learning process ? Later, the writer would like to discuss deeper and wider about the Class Average of 2013 generation, so it needs the detail data. 
The Class Average of 2013 generation, especially $\mathrm{E}$ class achieved the lowest Class Average than the 2012 and 2011 generations. The writer had conduct the research about the Comparison Class Average of 2012 and 2011 generations on last semester.

The generations of 2012 and 2011 nursing students achieved the Class Average more than 65 point. But the 2013 generation, E class students achieved the Class Average is 56.80 point. It means the lowest one than two generations previously.

Herewith the data Class Average of English II for the seventh semester of 2013 generations. The total classes are five classes of 2013 generations.

\section{GRAFIK NILAI TAHUN AJARAN 2016-2017 \\ NILAI BAHASA INGGRIS II SEMESTER VII PRODI : Keperawatan (ANGKATAN 2013)}

\begin{tabular}{|l|c|l|l|l|}
\hline $\begin{array}{l}\text { NO } \\
\cdot\end{array}$ & Kelas & $\begin{array}{l}\text { Jmlh } \\
\text { Mhsw }\end{array}$ & $\begin{array}{l}\text { TOTA } \\
\text { L }\end{array}$ & $\begin{array}{l}\text { RAT } \\
\text { A } \\
\text { RAT } \\
\text { A }\end{array}$ \\
\hline l. & A & 45 org & 2.729 & 60.64 \\
\hline 2. & B & 5 org & 3.226 & 65.21 \\
\hline 3. & C & 40 org & 2.649 & 66.22 \\
\hline 4. & D & 35 org & 2.246 & 64.17 \\
\hline 5. & E & 42 org & 2.386 & 56.80 \\
\hline
\end{tabular}

After the writer describes about the point and table graphic. The writer would like to discuss or conduct in depth analysis. From five classes, there are only E class shows the contrast of Class Average is 56.80. It means Class Average of $\mathrm{E}$ class performs the lowest one of Class Average. The others classes states of Class Average around 60 points. And $\mathrm{C}$ class performs the highest of Class Average (66.22 point).

Herewith the Obtaining data point of English II for the seventh semester of 2013 generations of E class. The total numbers are 42 students.

$$
\begin{array}{lc}
A+=0 \text { students } & B+=3 \text { students } \\
A=0 \text { student } & B \quad=7 \text { students } \\
A-=2 \text { students } & B-=6 \text { students } \\
\text { C }=4 \text { students } & \mathrm{D}=8 \text { students } \\
\mathrm{C}=6 \text { students } & \mathrm{E}=0 \\
\mathrm{C}=2 \text { students } &
\end{array}
$$

From the data provides about the Obtaining process of English II point for the seventh semester of one generation in details. From this data, the writer can conduct the In Depth Analysis process.

According to the data above performs there is no students that can achieve A+ and A point The data proves, it means there is zero or on one can attain A+ and $\mathrm{A}$ point of $\mathrm{E}$ class. As contradictory, there are many students get $\mathrm{C}+$ point (4 students), C point (6 students), and C-point (2 students), finally D point (8 students). All of these students achieved the standard point $\mathrm{C}+$ down to $\mathrm{D}$. These numbers totally 
are 20 students. It means almost a half of $\mathrm{E}$ class get below of standard point. Because totally students numbers of E class are 42 students.

Every generations of nursing students have their own characteristics. This time the writer does not doing the analysis why the generation of 2013 performs the lowest Class Average than compare 2012 and 2011 generation achieve- ment. But the writer conduct about the depth analysis only on 2013 generation of nursing students, specially E class.

All of this Class Average achievement scores indicate a significant correlation that a fairly low interest about English. So, the 2013 generation of nursing students, especially E class performs the lowest Class Average because of low interest, likeness, etc.

There are some aspects that quite relevant with the interest scope. The writer would like to describe about this scope clearly.

The interest is one of the main aspects from teaching learning process. An interest is the first step for someone to do something because of likeness. Without any interest someone reluctant to do or something could not be well done. On teaching learning process interest aspect plays the important role to accomplish the assignment, doing well the mid and final test. Because of interest the students like and eager to attend the class of the whole running semester.

The definition of interest : is a feeling that accompanies or causes special attention to something or someone : concern. An interest is a noun (kata benda dalam Bahasa Indonesia yang berarti : minat, ketertarikan, perhatian) and has meaning attention that is given to or received from someone or something. Furthermore, the writer would like to describe vividly about the data of 2013 generations nursing students.

Because of an interest, the students can achieve the Class Average above of 60 point. An interest will be the first step to do something seriously. Without interest is impossible to have motivation to do something. From an interest first step, the teaching learning process would be happen seriously and ending with good result. An interest side could support or create another aspects, such as : 1. An eagerness to study seriously.

An eagerness is quite difficult aspects that we can find on this digital generations. This generations tend to be an instant generations. They are reluctant to do the strong effort. They would like to accept the result without any hard work. They can do the process of teaching learning but they just 
through the process, like the water flow. They rather avoid the dynamic of the teaching learning process.

2. Diligent to study or Persistent.

Diligent aspects consist of another side, that is persistent. Someone who is quite diligent, it means he / she is must be persistent. Diligent without persistent is could not produce the result of teaching learning process. Persistent without diligent it is impossible. It is unity, one coin has two sides. It could not be separated, inter related. 3. Never give up.

Never give up it means he / she does not easy to give up. On their study life, they must find many obstacle / many problems. The obstacles are part of its. They keep their eyes on the final goal of their study. They have motto for their life. We must go home with the graduate certificate after the graduation day. So, they suppose all the obstacles are not the big problems of their study life.

4. Not easy to feel satisfy of their point.

Feeling satisfy is an easy part of someone's life. When you are easy to feel satisfy, you will accept whatever will be done or will be happen. But contradictory, when you are not easy to feel satisfy of your point. It means you will "catch" a higher level of your study life by studying hard and big effort. You will eager to achieve the higher point of your study. It means, you must "run after" a better and higher achievement as the proof of your study life.

\section{CLOSING}

From the list data that already explains, it can be concluded that through the depth analysis, we can prove about some factors that effected the Class Average of 2013 generations, especially E class. The data performs the Class Average of E class 2013 generations are the lowest one than the other classes (the four classes). Some factors that effected are : 1. An eagerness to study seriously.

Diligent to study or persistent 3. Never give up. 4. Not an easy to feel satisfy of their point.

From many data confirm above, the researcher can perform about the conclusion. The 2013 generations nursing study program students has their own characteristic. One of the four classes, it is E class performs the lowest Class Average of their achievement.

\section{BIBLIOGRAPHY}

Ellis, R. (1996) The Study of Second Language, Oxford : Oxford Univ. Press.

Brown, D.H. (2007) Teaching by Principle ; An Interactive Approaches Language Pedagogy. $3^{\text {rd }}$ edition New York : Pearson Education. 
Bin Tahir, S. Z. (2017). Multilingual teaching and learning at Pesantren Schools in Indonesia. Asian EFL Journal, 89, 74-94.

Bin-Tahir, S., Hanapi, H., Mufidah, N., Rahman, A., \& Tuharea, V. U. (2019). Revitalizing The Maluku Local Language In Multilingual Learning Model. INTERNATIONAL JOURNAL OF SCIENTIFIC \& TECHNOLOGY RESEARCH, 8(10).

Bin-Tahir, S. Z., \& Rinantanti, Y. (2016). Multilingual lecturers' competence in english teaching at the university of Iqra Buru, Indonesia. Asian EFL Journal, 5, 7992.

Bin Tahir, S. Z. (2015). Multilingual behavior of Pesantren IMMIM students in Makassar. Asian EFL Journal, 86, 45-64.

Bin Tahir, S. Z. (2015). The attitude of Santri and Ustadz toward multilingual education at Pesantren. International Journal of Language and Linguistics, 3(4), 210-216.

Saidna Z, B. T., Haryanto, A., Syarifuddin, D., \& Yulini, R. (2017). Multilingual Instructional Model of Pesantren Schools in Indonesia. Journal of Language Teaching and Research, 8(6), 1210-1216.

Bin-Tahir, S. Z., Atmowardoyo, H., Dollah, S., Rinantanti, Y., \& Suriaman, A. (2018). MULTILINGUAL AND MONOMULTILINGUAL STUDENTS'PERFORMANCE IN ENGLISH SPEAKING. Journal of Advanced English Studies, 1(2), 32-38.

Bin-Tahir, S. Z., Suriaman, A., \& Rinantanti, Y. (2019). Designing English Syllabus for Multilingual Students at Pesantren Schools. Asian EFL Journal, 23(3.3), 5-27.

TAHIR, S. Z. A. B. (2017). Pengembangan Materi Multibahasa untuk Siswa Pesantren (Doctoral dissertation, Pascasarjana).

Bin-Tahir, S. Z., Atmowardoyo, H., Dollah, S., \& Rinantanti, Y. (2017). Multilingual learning program: pesantren students' perceptions of the multilingual simultaneous-sequential model. JELE (Journal Of English Language and Education), 3(2), 44-53.

Bin Tahir, S. Z. (2015). Multilingual Education in Pesantren Deepublish.

Bin-Tahir, S. Z., Hanapi Hanapi, I. H., \& Suriaman, A. (2020). Avoiding Maluku Local Languages Death Through Embedded Multilingual Learning Model: Menghindari Kematian Bahasa Daerah Maluku melalui Model Pembelajaran Embedded
Multilingual. Uniqbu Journal of Social Sciences, 1(1), 53-60.

Bin-Tahir, S. Z., Suriaman, A., Hanapi, H., Iye, R., \& Umanailo, M. C. B. (2020). Development of Buru Local Language Conversation.

Bin-Tahir, S. Z. (2015). Multilingual Teaching And Learning At Pesantren.

Tahir, S. Z. B., Atmowardoyo, H., \& Dollah, S. (2018). Belajar Berbicara Multibahasa Uuntuk Santri Pesantren. Deepublish.

Bin-Tahir, S., Hanapi, H., Mufidah, N., Rahman, A., \& Tuharea, V. U. (2019). Revitalizing The Maluku Local Language In Multilingual Learning Model. INTERNATIONAL JOURNAL OF SCIENTIFIC \& TECHNOLOGY RESEARCH, 8(10).

Tuharea, V. U., Tahir, S. Z. B., Ami, I. S. O., \& Rahman, A. (2020). Buru Language Conservation Through Sustainable Mulok Learning In Buru Regency:(Konservasi Bahasa Buru melalui Pembelajaran Mulok Berkelanjutan di Kabupaten Buru). Uniqbu Journal of Social Sciences, 1(2), 49-55.

Bin-Tahir, S. Z., \& Hanapi, H. (2020). Designing the Indonesian Local Language Learning in English Teaching at the Multilingual Classroom Context. Asian EFL Journal, 27(32), 108-120.

Bin-Tahir, S. Z., Tenriawali, A. Y., Umanailo, M. C. B., Hasyim, M., Latjuba, A. Y., \& Abbas, A. (2021). Designing English Teaching Model at the Remote Area Schools of Maluku in Covid-19 Pandemic Situation. In Proceedings of the International Conference on Industrial Engineering and Operations Management (pp. 3933-3939).

Tahir, S. Z. B. (2021, March). Designing English Teaching Model at the Remote Area Schools of Maluku in Covid-19 Pandemic Situation. In Proceedings of the 11th Annual International Conference on Industrial Engineering and Operations Management. Universitas Iqra Buru.

Hewings, Martin (2002), Advanced Grammar in Use, 2nd edition, Cambridge, England, Penerbit Erlangga.

Michael Swan. 1982. Practical English Usage, Oxford. Oxford University Press.

Nunan, D. (2003) Practical English Teaching, New York : Mc. Grow Hill Companies.

Nunan, D, (1992) Research Methods in Language Learning, Cambridge : Cambridge Univ. Press.

Suryadi, Junaida S. Pd. (2007) Complete English Grammar, 2nd edition, Yogyakarta, Penerbit Pustaka Pelajar.

Supono, Idi (2007), English Grammar, 1st edition , Jakarta, Penerbit Wahyu Media. 